ZMAGO SKOBIR, B.Sc.

E-mail: zmago.skobir@lju-airport.si

Ljubljana Airport

Zg. Brnik 130a, SI-4210 Brnik-aerodrom, Slovenia

TONE MAGISTER, Ph.D.

E-mail: tone.magister@sloveniacontrol.si

Slovenia Control, Slovenian Air Navigation Services

Kotnikova 19a, SI-1000 Ljubljana, Slovenia
Transport Engineering

Preliminary Communication

Accepted: Sep. 7, 2009

Approved: Mar. 8, 2011

\title{
ASSESSMENT OF A LIGHT UNMANNED AIRCRAFT GROUND IMPACT ENERGY
}

\begin{abstract}
The subject of investigation are unmanned aircraft lighter than $150 \mathrm{~kg}$ under control by national aviation authorities and therefore prudently requiring harmonized individual state regulations. Originated from a general premise that the unmanned aircraft regulations should evolve from the existing standards for manned aircraft of equivalent class or category, the light fixed wing unmanned aircraft equivalence to the manned aircraft is defined in the form of sets of equivalency and non-equivalency based on the established administrative type of methodology of impact kinetic energy comparison. The basic flight characteristics of the existing operational light fixed wing unmanned aircraft are analyzed assuring proper input for determination of the more realistic unmanned aircraft impact kinetic energy in controlled and uncontrolled flight into terrain crash scenarios used for the evaluation of established methodology adequacy for equivalence determination. It is shown in the paper that determination of the unmanned aircraft equivalency to the manned aircraft should not be based on the unmanned aircraft maximum take-off mass nor their airspeed range alone.
\end{abstract}

\section{KEYWORDS}

light unmanned aircraft, impact kinetic energy, hazard potential, classification

\section{INTRODUCTION}

In the foreseeable future it can be expected that the most numerous unmanned aircraft (UA) will be those with operational mass considerably less than $150 \mathrm{~kg}$ [7]. This broad family of relatively lightweight and small UA comprises Micro UA weighing less than $5 \mathrm{~kg}$, Mini UA weighing up to $25(30) \mathrm{kg}$ as well as Close Range UA with an operational mass between 25 and $150 \mathrm{~kg}$, and they are serviceable for wide variety of military and non-military operations (i.e. markets). From commercial and/or user point of view the basal purpose of UAS flight operations is to observe ground installations and activities including human activities.
The capabilities of most on-board sensory equipment of the lightest UA weighing up to $30 \mathrm{~kg}$ will drive their flight operations to low altitudes close to the point of interest resulting in deliberate and frequent flying in the close proximity of populated areas or even overflying people.

Insufficient experience regarding UA reliability, the inability to define UA mishap probability, and the lack of knowledge about the hazardousness of a UA mishap, and so the complex risk associated with UA flight operations, has led to authorities placing restrictions on where and how UAs are operated. These restrictions include segregating UA operations from other airspace users and denying them the airspace above populated areas for the protection of people on the ground $[2,5,8,9,12]$.

The UAS flight operations are acceptable if and only if they are at least as safe as the operations of manned aircraft insofar as they must not present or create a greater hazard to persons or property whilst in the air or on the ground, than that attributable to the operations of a manned aircraft of equivalent class or category $[2,5,8,12]$. Accordingly, the UAS regulations and their airworthiness standards should evolve from the existing standards for manned aircraft of equivalent category $[5,8]$. Additionally, the general UA related policy is aiming towards relaxed regulations of simple and realizable requirements and standards to facilitate UA technology development while maintaining public safety $[1,2,8,12]$.

The problem addressed is: "How to establish equivalence between unmanned aircraft weighing less than $150 \mathrm{~kg}$ and mainly, but not exclusively, heavier manned aircraft?" Another level of basically the same problem is the definition of classificatory limits for delineation of a wide group of UA weighing up to $150 \mathrm{~kg}$ and having potentially significantly different hazard to the third parties footprint. Such a subclassification should facilitate the idea of increasingly demanding 
requirements of relaxed regulation of the lightweight and small UA. Therefore, the research objective is the definition of the unmanned aircraft weighing less than $150 \mathrm{~kg}$ equivalence to the manned aircraft in the form of sets of equivalency and non-equivalency based on the methodology of impact kinetic energy comparison. Accordingly, the flight characteristics of the existing operational fixed-wing UA systems weighing less than $150 \mathrm{~kg}$ are analysed assuring the input for determination of the realistic UA impact kinetic energy in controlled and uncontrolled flight into terrain crash scenarios used for the evaluation of the methodological adequacy for equivalence determination.

\section{UNMANNED AIRCRAFT IMPACT KINETIC ENERGY}

\subsection{Unmanned Aircraft hazard potential criterion}

Assuming UA flight operations over populated areas the risk of injury to the humans has to be kept to an acceptable minimum. Injuring a human bystander will only be one of the possible consequences following a UA unintentional flight termination and crash (controlled or uncontrolled flight into terrain) as shown by the chain of events three in Figure 1 comprising the safety critical events and their mutually exclusive complementary events. One straightforward way to accomplish zero risk to human goal is to completely ban UA flights over the populated areas. However, considering the commercial and UA final product user interests this might not be a viable long-term option.

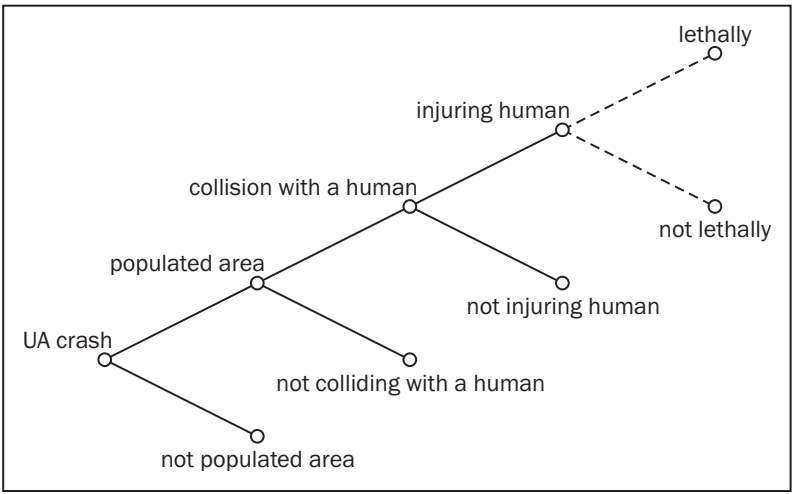

Figure 1 - Safety critical chain of events tree

The UA capability of injuring human should be proportionally correlated with the energy released to the human body upon impact of the UA or its parts after the impact with the ground or in-flight fragmentation. Therefore, the UA impact kinetic energy can be considered as an indicator of the level of risk associated with the UA operations. The parameters defining UA impact kinetic energy can be used as a basis for defining the
UA physical properties contained in a set of airworthiness requirements as well as for operational limitations or restrictions.

The UA impact kinetic energy $K E_{i m p}$ is defined by:

$K E_{i m p}=\frac{m v_{i m p}^{2}}{2}$

the UA maximum take-off mass (MTOM) $m$, and the UA impact ground speed $v_{\text {imp }}$, which in still weather equals the airspeed, and depends upon the UA crash scenario. The relevant UA impact speed range follows from two UA crash scenarios:

a) controlled flight into terrain (CFIT) in level flight at an operational airspeed $v$ with an impact that arises prior to the emergency landing attempt,

b) uncontrolled flight into terrain (UFIT) in the worst case scenario of a vertical dive commenced at operational airspeed $v$.

\subsection{Controlled flight into terrain scenario}

From the data of (the incomplete set of) the existing operational light fixed wing UA of which the MTOM does not exceed $150 \mathrm{~kg}$ the UA operational airspeed range $v=\left[v_{\min }, v_{\max }\right]$, ranging from the UA minimum airspeed $v_{\min }$ to the UA maximum level flight airspeed $v_{\text {max }}$, including the UA cruise airspeed $v_{C} \in\left[v_{\text {min }}, v_{\text {max }}\right]$ as a function of UA MTOM $m$ can be derived:

$v_{\min }=10.06_{ \pm 0.69}+0.095_{ \pm 0.01} m\left[\frac{\mathrm{m}}{\mathrm{s}}\right]$

$v_{C}=15.15_{ \pm 0.87}+0.121_{ \pm 0.013} m\left[\frac{m}{s}\right]$

$v_{\max }=26.02_{ \pm 1.29}+0.126_{ \pm 0.02} m\left[\frac{\mathrm{m}}{\mathrm{s}}\right]$

The UA operational airspeed range (2) demonstrates that the light UA minimum i.e. stall airspeed $v_{\text {min }}$ ranges (at $R=0.87 ; S D=2.61$ ) from 10 to $25 \mathrm{~m} / \mathrm{s}(19-49 \mathrm{kt})$, the cruise airspeed $v_{C}$ of the light UA ranges (at $R=0.87 ; S D=3.29$ ) from 15 to $35 \mathrm{~m} / \mathrm{s}$ (29-68kt), while the light UA maximum airspeed $v_{\max }$ ranges (at $R=0.78 ; S D=4.86$ ) from 25 to $45 \mathrm{~m} / \mathrm{s}$ (49-88kt) as shown in Figure 2.

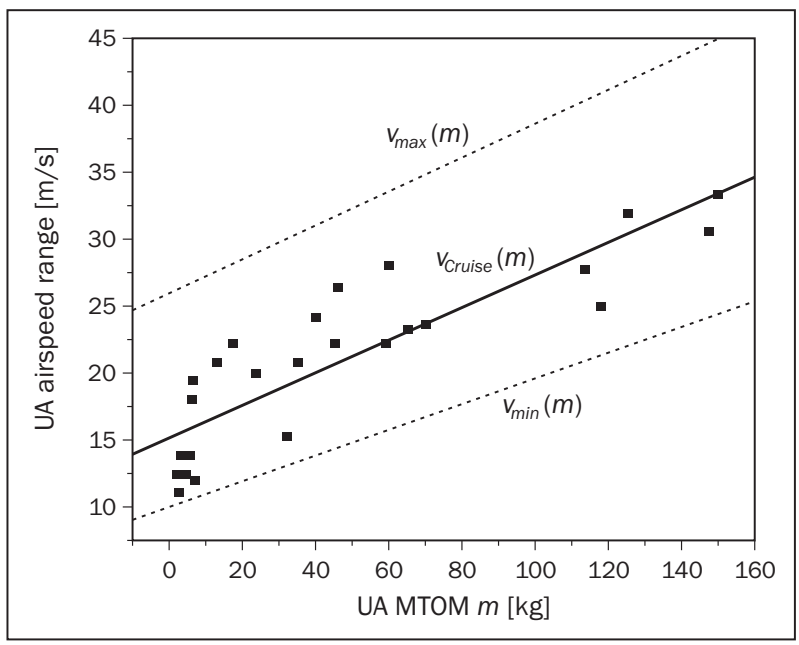

Figure 2 - Light UA airspeed range 


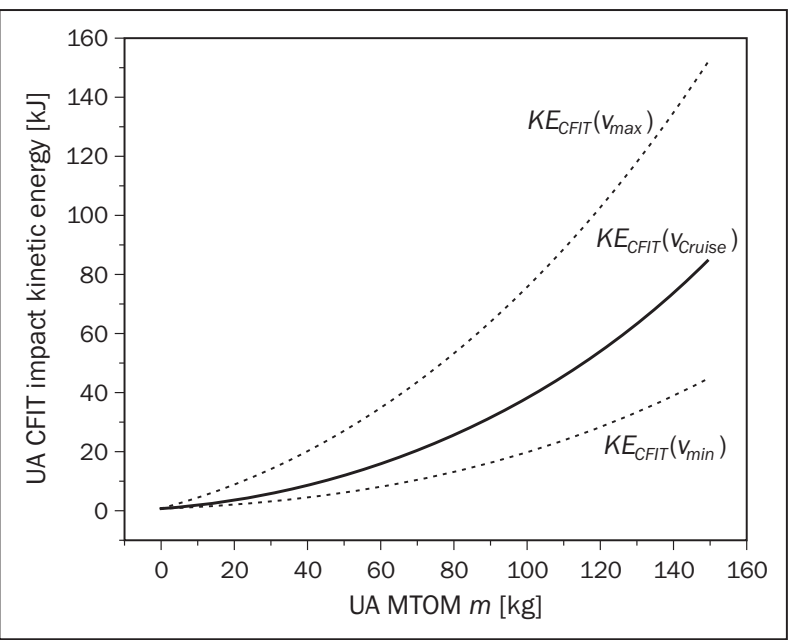

Figure 3 - Light UA CFIT impact kinetic energy

Substituting the UA operational airspeed range $v=\left[v_{\min }, v_{\max }\right](2)$ into (1) results in the light UA controlled flight into terrain (CFIT) kinetic energy at impact with the operational airspeed. In Figure 3 the light UA CFIT kinetic energy levels, exponentially increasing with their MOTM, are presented for impacts at the characteristic airspeed from their operational airspeed range, namely $v_{\min }, v_{C}$, and $v_{\max }$; numerical representation of results is provided in Table 1.

\subsection{Uncontrolled flight into terrain scenario}

For the worst case UA uncontrolled flight into terrain (UFIT) crash scenario impact kinetic energy determination, the UA impact velocity after vertical dive initiated at the UA flight height above ground $h$ and the initial operational airspeed $v$ can be, originated from $a(u)=g-\left(A \rho c_{D} u^{2}\right) / 2 m$, written as:

$$
u(h)=\sqrt{w^{2}-\left(w^{2}-v^{2}\right) \exp \left(-\rho A c_{D} m^{-1} h\right)}
$$

where $a$ and $u$ are the vertical dive $U A$ acceleration and airspeed, $w=\left(2 \mathrm{mg} / \rho A c_{D}\right)^{1 / 2}$ is the UA terminal velocity, $g$ is the gravitational acceleration, $\rho$ is the air density, $m$ is the UA mass, $A$ is the UA wing area, and $c_{D}$ is the UA aerodynamic drag coefficient. For the sake of simplicity, the UA dive speed model (3) assumes immediate engine cut-off, as foreseen by existing applicable regulations, and neglects the drag increase of the windmilling or feathered propeller.

The light UA wing loading $m / A$ can be derived as a function of the UA MTOM $m$ from data of the existing operational fixed wing UA with MTOM less than $150 \mathrm{~kg}$ :

$\frac{m}{A}=8.102_{ \pm 1.0}+0.286_{ \pm 0.012} m\left[\frac{\mathrm{kg}}{\mathrm{m}^{2}}\right]$,

demonstrating that the wing loading of the light UA ranges (at $R=0.98 ; S D=2.79$ ) from 8 to $51 \mathrm{~kg} / \mathrm{m}^{2}$ as shown in Figure 4.

Based on the existing data, the aerodynamic drag coefficient $C_{D}$ of fixed wing UA with MTOM less than

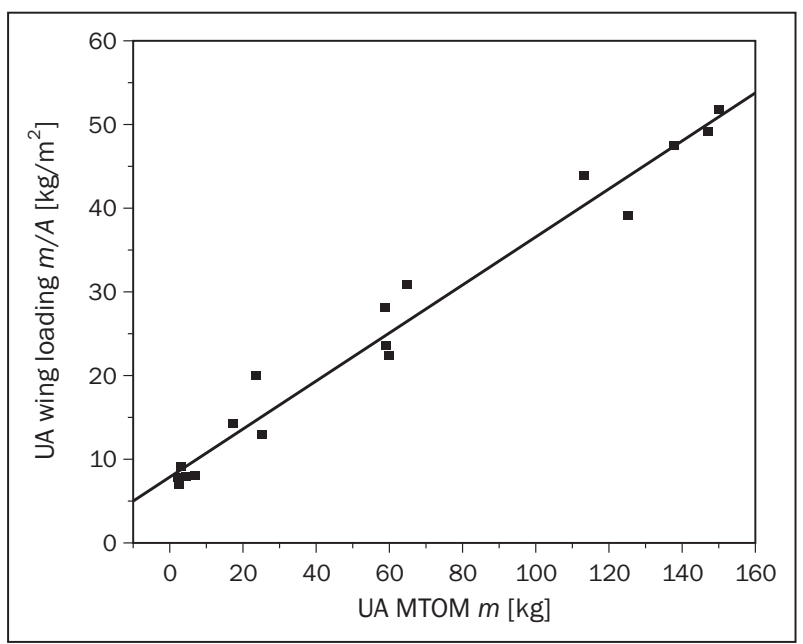

Figure 4 - Light UA wing loading

$150 \mathrm{~kg}$ can be expressed as a function of UA MTOM $m$ roughly as:

$c_{D}=0.193_{ \pm 0.004}+0.000261_{ \pm 0.000051} m$,

demonstrating that the light UA aerodynamic drag coefficient ranges (at $R=0.79 ; S D=0.01$ ) from 0.19 to 0.23 as shown in Figure 5.

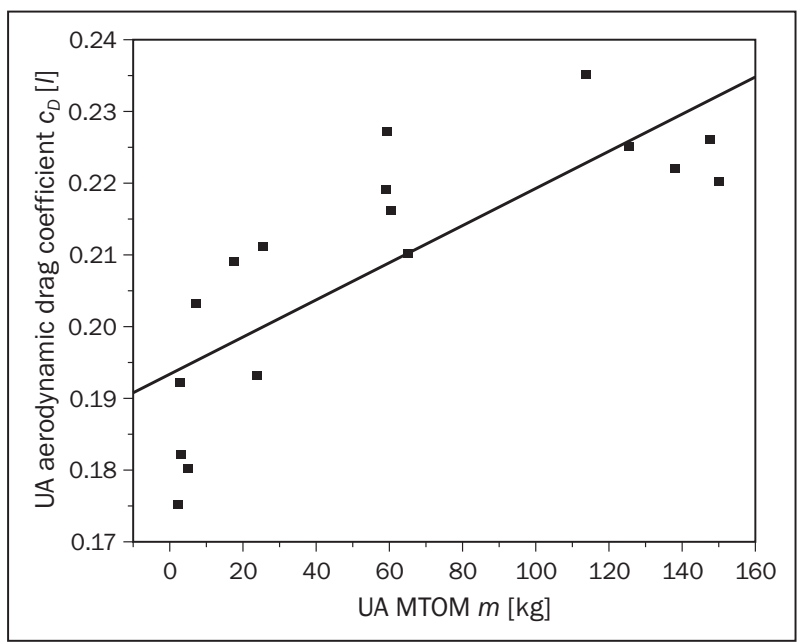

Figure 5 - Light UA aerodynamic drag coefficient

UA airspeed $u(3)$ in a vertical dive from the flight height $h$ that will result in the UA UFIT impact airspeed $v_{\text {imp }}$ is investigated in Figure 6 where the UA physical properties of $m / A(4)$ and $c_{D}(5)$, and the UA operational airspeed range $v=\left[v_{\min }, v_{\max }\right]$ (2) were considered.

It is obvious from Figure 6 that if the UA vertical dive starts high enough the UA will impact with a constant airspeed. Namely, as described by the airspeed functions $u(h)(3)$, when the aerodynamic drag equals weight the UA's airspeed in vertical dive asymptotically approaches its terminal velocity $w$ :

$w=\sqrt{\frac{2 m g}{\rho A c_{D}}}$ 


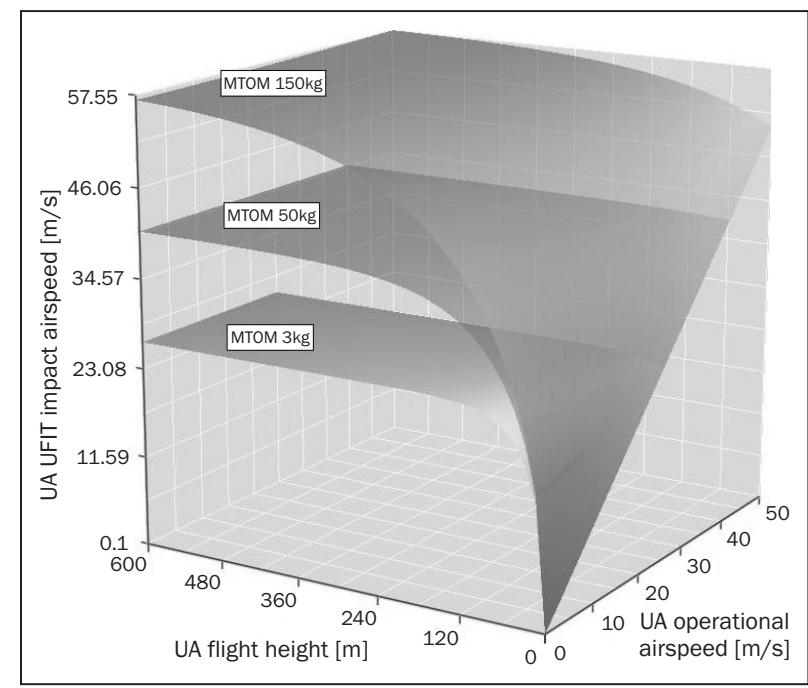

Figure 6 - Light UA vertical dive UFIT impact airspeed

It should be noted that the assessment of the light UA terminal velocities $w$ of Figure 6 and (6), ranging from approximately 25 to $60 \mathrm{~m} / \mathrm{s}$ (49-116kt) are conservative, representing the worst case scenario, since they are based upon the UA aerodynamic drag coefficient $c_{D}$ function (5) and Figure 5 which was derived for the UA at maximum airspeed attainable at level flight using full available power. Consequently, it is reasonable to expect that the $c_{D}$ of UA in uncontrolled flight would have greater values resulting in terminal velocities lower than those in Figure 6 as well as lower UA UFIT impact kinetic energy levels than those presented in Figure 7. However, Figure 6 reveals that the higher the heavier UA flies its UFIT impact velocity $v_{\text {imp }}$ will be less affected by the UA operational airspeed $v$ at which the uncontrolled dive starts since the UA will impact with its terminal velocity $v_{T}$. For example the UA with MTOM of $3 \mathrm{~kg}$ will reach its terminal velocity after approximately $120 \mathrm{~m}$ (400ft) drop in a vertical dive, and with MTOM of $150 \mathrm{~kg}$ the UA's UFIT impact velocity will

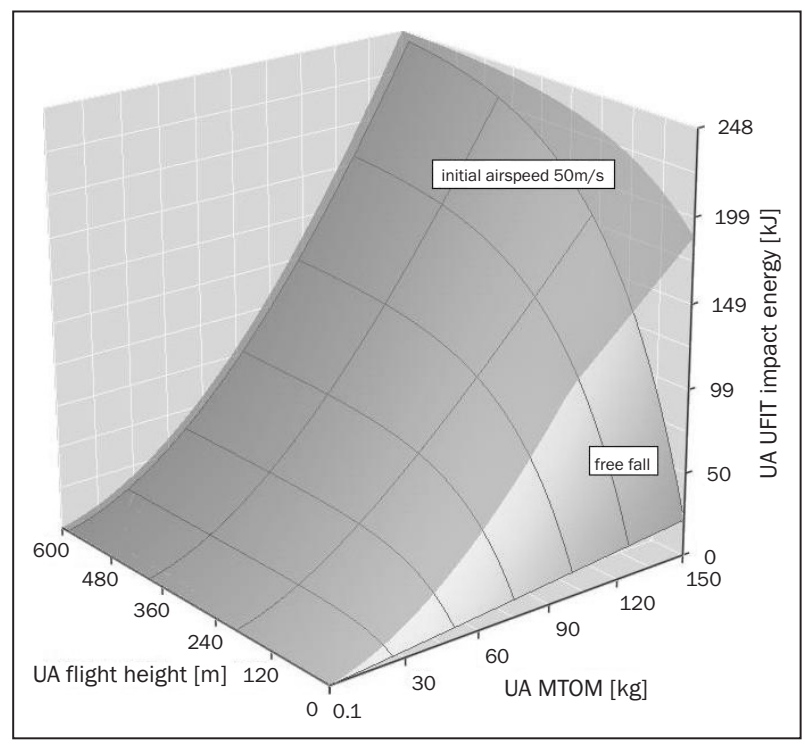

Figure 7 - Light UA UFIT impact kinetic energy

equal its terminal velocity if uncontrolled vertical dive starts approximately $600 \mathrm{~m}(2,000 \mathrm{ft})$ above ground.

Substituting UA airspeed function $u(h)$ (3) which could not exceed the UA terminal velocity $w$, into (1), and considering the UA physical properties $m / A$ (4) and $c_{D}(5)$ as well as the vertical dive initial airspeed within the UA airspeed range $v=\left[v_{\min }, v_{\max }\right](2)$, yields in the light UA UFIT impact kinetic energy the results shown in Figure 7; numerical representation of results is provided in Table 1.

\section{UNMANNED AND MANNED AIRCRAFT COMPARISON}

The UA operations must be at least as safe as the operations of manned aircraft insofar as they must not present or create a greater hazard to persons or property whilst in the air or on the ground, than the one

Table 1 - Light UA impact kinetic energy (numerical representation)

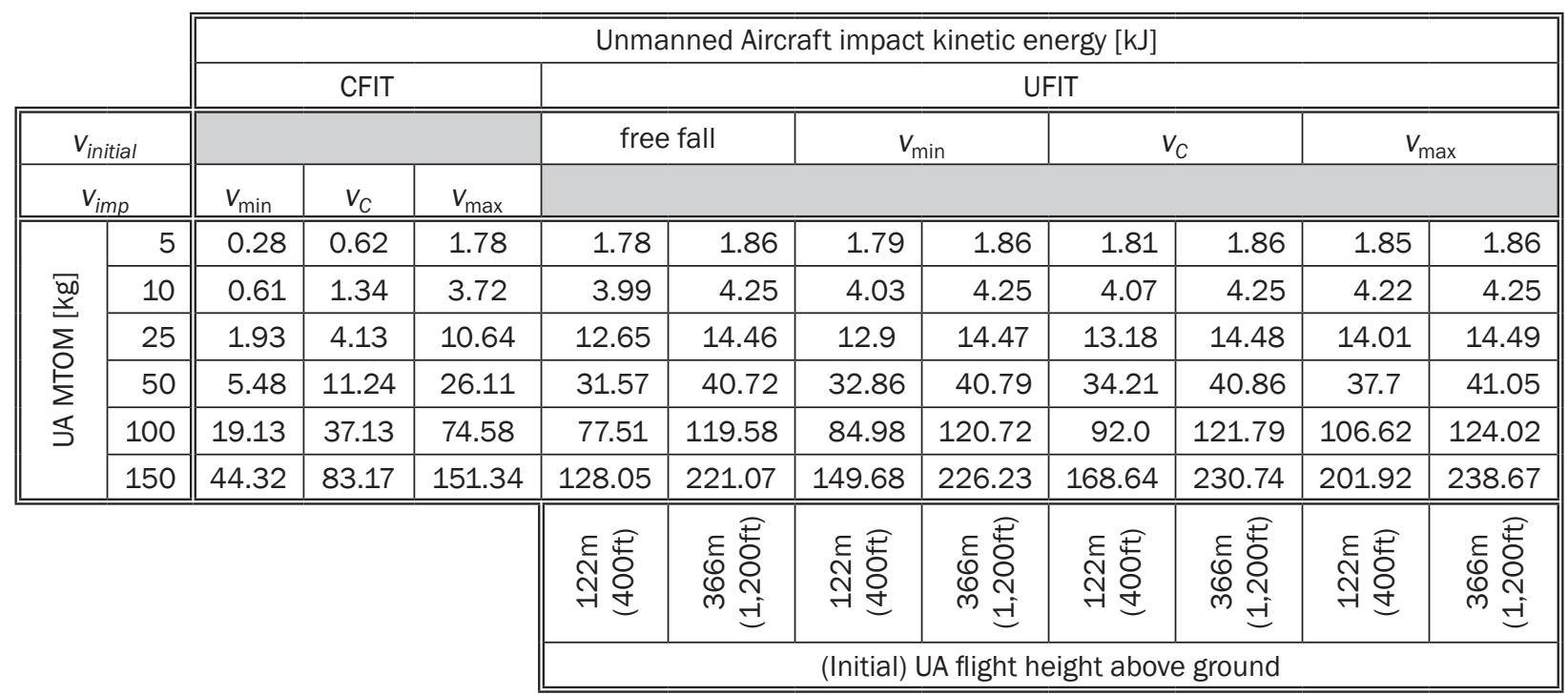


attributable to the operations of a manned aircraft of equivalent class or category. To establish equivalence between UA weighing less than $150 \mathrm{~kg}$ and mainly, but not exclusively, heavier manned aircraft it is convenient to use a method for setting design standards for new kinds of aircraft, including UA/UAS proposed by [8] and reused in [5]. The fundamental purpose of methodology is comparing UA/UAS with the existing fleet of conventional aircraft and by doing so generate the outline of the appropriate standards to be applied by reference to the existing codes which contribute to the currently accepted level of safety [8]. The methodology introduces impact kinetic energy as a proportional factor to the aircraft hazard potential in two impact scenarios:

a) unpremeditated descent scenario (UDS) with impact while UA is under control but unable to maintain altitude for which the fixed wing UA (aeroplane) impact airspeed contained in (2) is defined as [8]:

$v_{\text {impUDS }}=1.3 v_{\text {min }} @ M T O M$

b) Ioss of control scenario (LCS) for which the fixed wing UA (aeroplane) impact airspeed contained in (2) is defined as [8]:

$v_{\text {impLCS }}=1.4 v_{\text {max }} @ M T O M$

Results of methodology employed are presented in Figure 8 for the unpremeditated descent scenario, where $v_{\min }(m)$ from (2) and (7) are applied in (1), and in Figure 9 for the loss of control scenario, where $v_{\max }(m)$ from (2) and (8) are applied in (1). The applicable "equivalence region" for each of the existing aeroplane codes shown in Figures 8 and 9 are recalculated from [8] where "applicability regions" were defined by kinetic energy calculated for a selection of different existing aircraft, in addition manned aircraft classification data of [3], and [6] were used.

Solution of (1) equated to the corresponding "equivalence region" kinetic energy limit while applying (7) and (2) indicates the light UA weighing less than $150 \mathrm{~kg}$

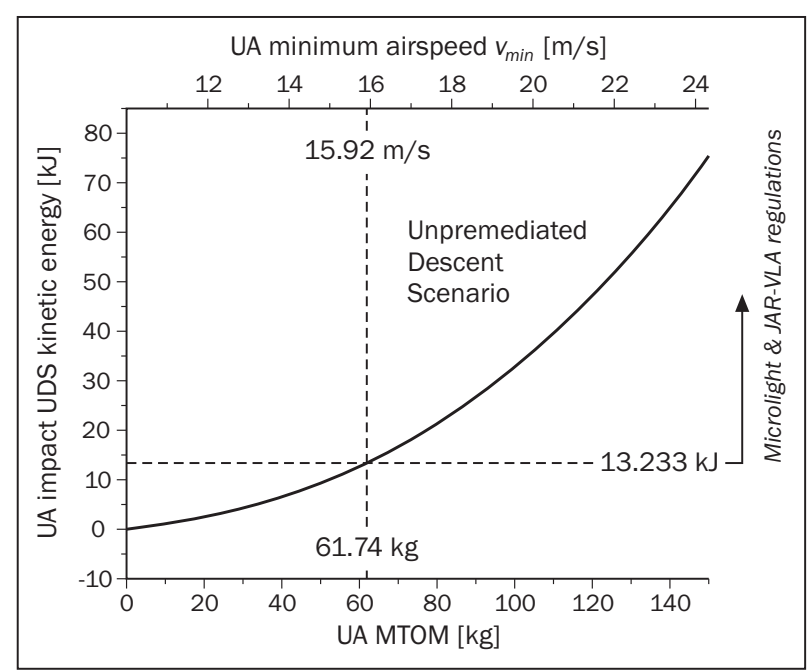

Figure 8 - Light UA unpremeditated descent scenario

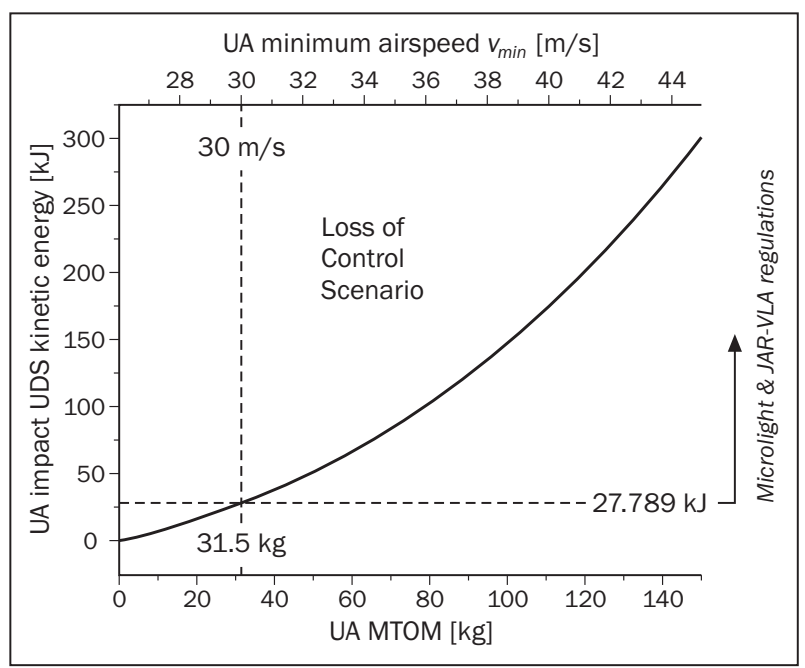

Figure 9 - Light UA loss of control scenario

equivalency to the manned aircraft, that is, the existing light fixed wing UA should be considered equally equivalent to either microlight or very light aircraft:

a) under the unpremeditated descent scenario (Figure 8) if the UA is an element of the equivalency set:

$E Q_{U D S}=\left\{\left(m, v_{\min }\right) \mid m>61.7 \mathrm{~kg} ; v_{\min }>\frac{125.14}{\sqrt{m}} \frac{\mathrm{m}}{\mathrm{s}}\right\}$

b) under the loss of control scenario (Figure 9) if the $\mathrm{UA}$ is an element of the equivalency set:

$E Q_{L C S}=\left\{\left(m, v_{\max }\right) \mid m>31.5 \mathrm{~kg} ; v_{\max }>\frac{168.39}{\sqrt{m}} \frac{\mathrm{m}}{\mathrm{s}}\right\}$

The sets (9) and (10) of light UA equivalent to the appropriate category of manned aircraft are summarized and presented in Figure 10.

Furthermore, Figure 10 indicates the UA minimum $v_{\min }(m)$ and maximum $v_{\max }(m)$ airspeed limits range functions of the UA MTOM $m$ for the UA that, using established impact kinetic energy methodology [8], [5], should not be regarded as equivalent to the manned aircraft. Accordingly, the UA with an MTOM $m$, that can range up to $150 \mathrm{~kg}$, should not be considered equivalent to the manned aircraft if it is an element of a nonequivalent set:

$$
\begin{gathered}
N E Q=\left\{\left(v_{\min }(m), v_{\max }(m)\right) \mid v_{\min }<\frac{125.14}{\sqrt{m}} \frac{\mathrm{m}}{\mathrm{s}} ;\right. \\
\left.v_{\max }<\frac{168.39}{\sqrt{m}} \frac{\mathrm{m}}{\mathrm{s}}\right\}
\end{gathered}
$$

\section{DISCUSSION}

The UA impact energy potential analysis provides an evidence that the existing set of operational fixed wing UA weighing less than $150 \mathrm{~kg}$ poses significant level of impact kinetic energy either in the CFIT (Figure 3) or UFIT (Figure 7) crash scenario. Importantly, 


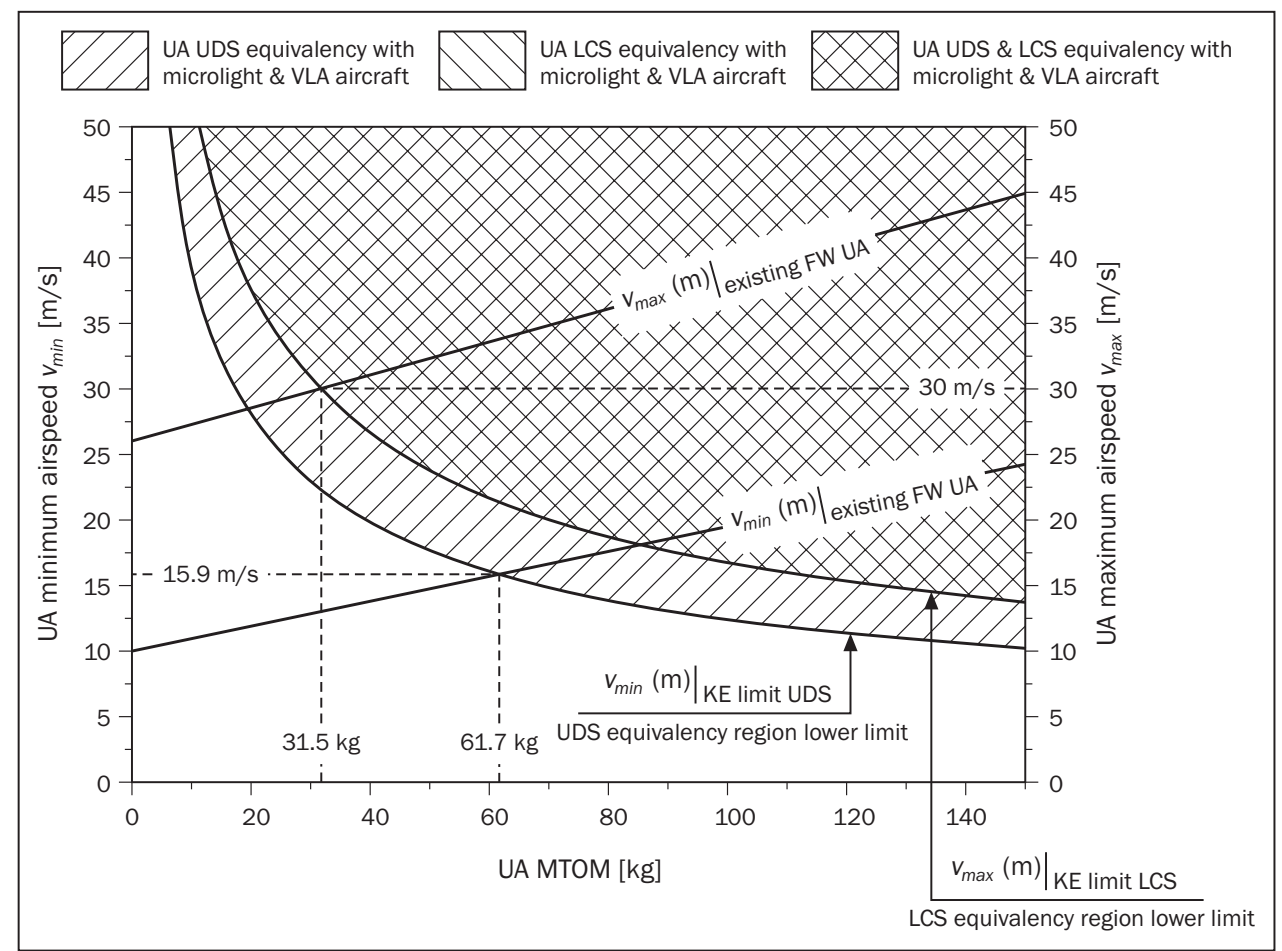

Figure 10 - Light UA equivalency with manned aircraft

the kinetic energy upon light UA impact reaches values that are at least three orders of magnitude greater from what is currently considered as positively lethal to humans. Namely, according to [11] a 0,5 kg object with kinetic energy of $50 \mathrm{~J}$ has a probability of causing a fatality of $10 \%$, while for more than $200 \mathrm{~J}$ that probability rises to above $90 \%$; furthermore, the munitions are regarded as nonlethal if they impact with kinetic energy below $78 \mathrm{~J}$ [10].

Light UA UDS impact kinetic energy (Figure 8) is comparable to the light UA CFIT kinetic energy at impact with the cruising airspeed $v_{C}$ (Figure 3 ). Considering that both scenarios are based upon the UA minimum airspeed i.e. the UA stall speed the discrepancy is due to the safety factor of 1.3 introduced in $v_{\text {impUDS }}$ (7). If safety factor of $v_{\text {impuDs }}(7)$ is reduced (or even neglected), the lower limit of UDS equivalency region (Figure 10) would rise due to the reduced UA impact kinetic energy of UDS (Figure 8), resulting in increased set (11) of UA considered of being not equivalent to the manned aircraft. Accordingly, the MTOM of the light existing fixed wing UA considered equivalent to both microlight and very light aircraft (9) would increase (Figures 8 and 10).

Similarly, the light UA LCS impact kinetic energy (Figure 9) is comparable to the light UA impact kinetic energy of UFIT crash scenario (Figure 7) since the safety factor of 1.4 introduced in $v_{\text {impLCS }}(8)$ increases the UA maximum airspeed $v_{\max }$ into the range of its terminal velocity $w$ (comparing the $v_{\max }(m)$ function (2) with $w(6)$ based on $m / A(4)$ and $c_{D}$ (5) results in $\left.1.5 v_{\max }\left(\lim _{m \rightarrow 0} m\right)<v_{T}<1.37 v_{\max }(m=150 \mathrm{~kg})\right)$. Nota- bly, the LCS by increasing UA $v_{\max }(8)$ intrinsically assumes that the UA will impact at airspeeds of $w$ magnitude meaning that UA flies at an altitude sufficient to accelerate in LCS to reach $w$ comparable airspeeds. Taking into account operational constraints imposed to the UA weighing less than $150 \mathrm{~kg}$ regarding operational flight height above ground (for example [1, 2, 12]), the LCS might be too conservative in comparing the unmanned and manned aircraft. While the UA UFIT impact kinetic energy is based upon the impact airspeed as a function of flight height $u(h)(3)$, the UA impact kinetic energy of LCS remains the same regardless of the operational flight height restrictions imposed to the different light UA subcategories. Because the lightest of light UA are reaching their $v_{T}$ after shorter fall than the heavier UA (Figure 6), the simplification of LCS computation of impact kinetic energy affects significantly the UA heavier than approximately $50 \mathrm{~kg}$ reducing the MTOM of the light existing fixed wing UA considered equivalent to both microlight and very light aircraft (10), (Figures 9 and 10).

By impact kinetic energy comparison the equivalence of UA with MTOM less than $150 \mathrm{~kg}$ and manned aircraft can be established. The equivalence of UA to the manned aircraft intensifies as the UA MTOM increases, while the UA MTOM still approaches $100 \mathrm{~kg}$ their $v_{\min }(2)$ or $m / A(4)$ are either comparable or even exceeding those of the lower end of the JAR/FAR Part 23 single engine type manned aircraft (American Champion 7GCAA Citabria or Cessna C150, for example). The latter undoubtedly supports the idea of increasingly restrictive UA regulations. For the wide group of 
existing light fixed wing UA with MTOM less than 150kg tripartite subcategorisation (Figure 10) based on their equivalency to the manned microlight and very light aircraft clarifies (9) and (10) with delineations at two distinctive parameter groups (MTOM, $\left.v_{\min }, v_{\max }\right)$ with the first defined as $(30 \mathrm{~kg}, 22 \mathrm{~m} / \mathrm{s}, 30 \mathrm{~m} / \mathrm{s})$, and the second as $(60 \mathrm{~kg}, 16 \mathrm{~m} / \mathrm{s}, 21 \mathrm{~m} / \mathrm{s})$. At least a theoretical chance exists to build the UA with any MTOM within the mass range up to $150 \mathrm{~kg}$ which would not be equivalent to the manned aircraft and being therefore subject to the least demanding and/or restrictive requirements, but such a UA would nevertheless have impact kinetic energy in the range from $13 \mathrm{~kJ}$ (of UDS) to $27.7 \mathrm{~kJ}$ (of LCS) (Figures 8 and 9) sufficient enough to inflict lethal injuries to humans. Intelligibly, the development of appropriate UA standards increasingly demanding to reflect the UA hazard potential and mirrored in the UA subclassification defined by substantiated delineations cannot be based on the UA impact kinetic energy investigation of the administrative type of methodology of LCS/UDS or of CFIT/UFIT scenarios alone.

Truly, there is no definitive agreement or consensus in literature on how the probability of fatality as a function of the kinetic energy on impact is best defined [4]. Therefore, and considering the discussion, the realistic light UA hazard potential to the $3^{\text {rd }}$ parties footprint must consider the consequences of the UA overflying populated areas including the on UA reliability-dependent probability of UA crash resulting in fatality and especially the human injury mechanism due to the impact of the UA.

\section{CONCLUSION}

Based on a general premise that the UA systems regulations should evolve from the existing standards for manned aircraft of equivalent category, the UA weighing less than $150 \mathrm{~kg}$ equivalence to the manned aircraft is defined in the form of sets of equivalency and non-equivalency based on the methodology of impact kinetic energy comparison. The results of equivalence determination indicate that the determination of the UA equivalency to the manned aircraft should not be based on the unmanned aircraft maximum take-off mass and airspeed range alone. The UA with an MTOM, that can range up to $150 \mathrm{~kg}$, should not be considered equivalent to the manned aircraft if it is an element of a non-equivalent set defined by the UA maximum takeoff mass MTOM, the minimum or stall airspeed of the UA and the UA maximum airspeed attainable in a level flight. For the wide group of the existing light fixed wing UA with MTOM less than 150kg tripartite sub-categorisation based on their equivalency to the manned microlight and very light aircraft clarifies with delineations at two distinctive parameter groups $\left(M T O M, v_{\min }, v_{\max }\right)$ with the first defined as ( $30 \mathrm{~kg}, 22 \mathrm{~m} / \mathrm{s}, 30 \mathrm{~m} / \mathrm{s})$, and the second as $(60 \mathrm{~kg}, 16 \mathrm{~m} / \mathrm{s}, 21 \mathrm{~m} / \mathrm{s})$.

\section{ACKNOWLEDGEMENTS}

This material is based on the work supported partially by the Slovenian Research Agency Grant No. M2 - 0118 and partially by the Slovenian Department of Defense Grant No. BPL1 631-44/2007. Opinions, interpretations, conclusions, and recommendations are those of the authors and are not necessarily officially endorsed.

\section{ZMAGO SKOBIR}

E-mail: zmago.skobir@lju-airport.si

Aerodrom Ljubljana, d. d.

Zg. Brnik 130a, 4210 Brnik-aerodrom, Slovenija

Dr. TONE MAGISTER

E-mail: tone.magister@sloveniacontrol.si Kontrola zračnega prometa Slovenije Kotnikova 19a, 1000 Ljubljana, Slovenija

\section{POVZETEK}

\section{EKVIVALENTNOST LAHKIH BREZPILOTNIH LATAL IN LETAL S POSADKO}

Predmet obravnave so brezpilotna letala, ki so lažja od $150 \mathrm{~kg}$ in posledično $v$ domeni nacionalnih letalskih uprav, zato je modro uskalditi zadevajočo regulativo posameznih držav. Izhajajoč iz splošne premise, da naj se regulativa brezpilotnih letal razvija iz obstoječe regulative za letala s posadko ekvivalentnega razreda ali kategorije, je $v$ obliki množic ekvivalentnosti ali neekvivalentnosti določena ekvivalentnost brezpilotnih letal z letali s posadko. Ta temelji na administrativnemu tipu uveljavljene metodologije primerjanja kinetične energije ob trku. Osnovne letalne značilnosti brezpilotnih letal so analizirane zato, da zagotovijo pravilna izhodišča določitvi realnejše kinetične energije trka brezpilotnega letala $v$ scenarijih zrušitve $v$ kontroliranem ali nekontroliranem letu. Slednje služi za oceno ustreznosti uveljavljene metodologije ugotavljanja ekvivalentnosti med brezpilotnimi letali in letali s posadko. Članek opisuje, da naj določanje ekvivalentnosti med brezpilotnimi letali in letali s posadko ne temelji zgolj na največji vzletni masi ter hitrostnemu razponu brezpilotnih letal.

\section{KLUUČNE BESEDE}

lahka brezpilotna letala, kinetična energija trka, nevarnostni potencial, klasifikacija

\section{LITERATURE}

[1] CAA NZ, Unmanned Aerial Vehicles - Issues paper, Civil Aviation Authority of New Zealand, Wellington, 2007.

[2] CAA UK, CAP 722: Unmanned Aerial Vehicles Operations in UK Airspace - Guidance, Civil Aviation Authority of United Kingdom, Directorate of Airspace Policy, London, 2008. 
[3] CAA UK, CAP 482, British Civil Airworthiness Requirements, Section S - Small Light Aeroplanes, Civil Aviation Authority of United Kingdom, Safety Regulation Group, Issue 4, 2008.

[4] Dalamagkidis, K., Valavanis, K.P., Piegl, L.A., On Integrating Unmanned Aircraft Systems into the National Airspace System - Issues, Challenges, Operational Restrictions, Certification, and Recommendations, Springer, 2009.

[5] EASA, Policy of Unmanned Aerial Vehicle (UAV) certification, Advance-Notice of Proposed Amendment (ANPA) No 16/2005, European Aviation Safety Agency, Koln, 2005.

[6] EASA, Certification Specifications for Very Light Aeroplanes CS - VLA, ED Decision 2003/18/RM, Brussels, 2003.

[7] Eurocontrol, Unmanned Aircraft Systems Market Outlook, Eurocontrol UAS ATM Integration Activity, European Aviation Safety Agency, Brussels, 2008.

[8] Haddon, D.R., Whittaker, C.J., Aircraft Airworthiness Certification Standards for Civil UAVs, Civil Aviation Authority of United Kingdom, London, 2002.
[9] Haddon, D.R., Whittaker, C.J., UK-CAA Policy of Light UAV Systems, Civil Aviation Authority of United Kingdom, London, 2004.

[10] Hagarty, R.J., Joint Non-Lethal Weapons Program: NonLethal Mortar Cartridge, US Army Office of the Project Manager for Close Combat Systems, Picatinny Arsenal, NJ, 2003.

[11] RSG-RCC, Range safety criteria for unmanned air vehicles - rationale and methodology supplement, Range Safety Group - Range Commanders Council, Supplement to Doc. 323-99, 1999.

[12] sUAS ARC, Comprehensive Set of Recommendations for Small Unmanned Aircraft Systems Regulatory Development, Small Unmanned Aircraft System Aviation Rulemaking Committee, Washington, 2009.

[13] Wiklund, E., Flying with Unmanned Aircraft in airspace involving civil aviation activity - Air safety and the approvals procedure, The Swedish Aviation Safety Authority, Norrkoping, 2003. 